\title{
Exit, Voice or Loyalty? VET Stakeholders' Response to Large Scale Skilled Emigration From Poland
}

\author{
Kaja Reegård ${ }^{\star 1}$, Horacy Dębowski \\ ${ }^{1}$ NIFU Nordic Institute for Studies in Innovation, Research and Education, \\ Department of Primary and Secondary Education, PO Box 2815 Tøyen 0608 Oslo, Norway \\ ${ }^{2}$ SGH Warsaw School of Economics, Institute of Philosophy, \\ Sociology and Economic Sociology, Wiśniowa Street no. 41, 02-520 Warsaw, Poland
}

Received: 10.11.2019, Accepted: 04.05.2020, Published: 16.11.2020

\begin{abstract}
Context: The topic of this paper is how mass emigration of skilled workers affects national policies, and employers' willingness to invest in Vocational Education and Training (VET) in Poland. In the wake of EU enlargement in 2004, Poland became one of the biggest sending countries for skilled labour to Western European countries. These massive outflows of skilled labour, not compensated by adequate inflows of equally skilled workers, have led to serious skills shortages, especially in the construction sector. The paper investigates whether emigration and immigration constitute a driving force for institutional change of the Polish VET system, by analysing policy development and the attitudes of VET stakeholders towards contributing to VET.
\end{abstract}

Approach: The paper focuses on the emigration of skilled construction workers in Poland. Drawing on Hirschman's (1970) framework, when faced with massive skills deficits construction companies are confronted with different options: i) withdraw from the VET system and find other training and recruitment options (exit), ii) attempt to improve conditions by turning to policy makers (voice), and/or iii) remain loyal to the VET system. The analysis is based on an interview study of decision makers responsible for VET policies, employers, chamber of Craft and trade unions, principals of vocational schools, teachers and representatives of regional examination boards.

Corresponding author: kaja.reegaard@nifu.no

ISSN: $2197-8646$

http://www.ijrvet.net

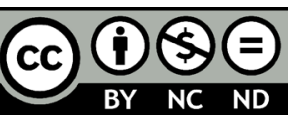


Findings: After years of inattention, VET has been regaining a strong position in national policies. We find that construction companies are mostly more willing now, compared to 5 years ago, to take on learners for practical training and to contribute to improving school equipment. The study showed that one of the most significant obstacles to employers investing in the training of VET learners is the fear of losing a young skilled employee through emigration. Yet, dependent on skilled labour, employers of big construction companies saw no other option than to continue investing in training young learners. However, smaller companies seeking the short-term benefits of employing low-cost labour are less interested in investing in VET.

Conclusion: Despite a range of recent policy actions and legislative efforts, several major challenges in the Polish VET system remain unresolved. Continued effort to institutionalise and enhance dialogue between the education system and the labour market appears as the most pressing need. It is currently too early to determine the degree of "institutional stickiness" of the activities observed on the policy level and among employers regarding their increased interest in VET as a response to mass skilled emigration.

Keywords: Vocational Education and Training, VET, Skilled Migration, Labour Shortage, Labour Mobility, Education-Industry Relationship, Educational Policy

\section{Introduction}

The last decades have seen far-reaching structural transformations due to the increased internationalization of labour markets. The impact of migration flows on national economies and productivity has gained considerable attention in the literature (Campanella, 2015; Campo et al., 2018; Nica, 2015; Beine et al., 2001). Debates on "brain drain" have been among the most prominent, emphasising that the emigration of high-skilled workers depletes human capital in the country of origin, which not only loses workforce but also the investment made in their education and training (Panzaru \& Reisz, 2017). However, how the emigration of skilled labour affects Vocational Education and Training (VET) systems in sending countries remains a largely under-theorised and under-researched field. This paper investigates how mass skilled emigration and low-skilled immigration affects national VET policies, and stakeholders' loyalty to the VET system in Poland.

After years of inattention, VET has been regaining a strong position in national policies since 2007 (Chłoń-Domińczak et al., 2011; Dębowski \& Stechly, 2015). This has partly been explained by changes in the labour market associated with the opening of European labour markets, which prompted an increase in national demand for workers with qualifications in skilled occupations (European Centre for the Development of Vocational Training [Cedefop], 2018). The heightened focus on VET has been supported by educational policies and 
funding from the EU level (Dębowski \& Stechly, 2015). The Polish VET system is organised in schools. However, strengthened linkages to employers are part of recent VET reforms aimed at increasing the relevance of VET to labour market needs, strengthening the quality of interactions between the actors from the education and labour market systems and ensuring a correspondence between skills supply and demand (Bolli et al., 2018).

The paper employs the emigration of skilled construction workers in Poland as its central case study, by investigating how the $2004 \mathrm{EU}$ enlargement represented a "shock" to the Polish labour market. Although construction was an early riser, other industries in the West have also benefitted heavily from the expanded craft labour base in Eastern Europe, such as shipyards, food processing industries and the service sectors (Andersen et al., 2009; Black et al., 2010; Hardy et al., 2012). Consequently, significant deficits in the labour force occurred in almost all sectors of the economy. Similar skills shortages in the construction sector are evident in countries such as USA (Toppin, 2018).

We explore the following two research questions: (1) What are the responses of VET poli$c y$, teachers and employers in the construction sector when confronted with labour shortages caused by large scale skilled emigration; and (2) to what extent does large scale skilled emigration affect VET policy, teacher and employer responses, leading to permanent changes in VET in Poland? In this effort, the paper brings together two previously disconnected strands of literature: VET research and labour migration research. The potential of this emerging avenue of research lies in addressing concepts, models, tensions, opportunities and innovations around the impact of migration flows on VET institutions, employers and learners.

In the wake of EU enlargement, a massive number of individuals from the New Member States embarked on their migration journeys westwards in search of better jobs and living conditions (Janicka \& Kaczmarczyk, 2016). Poland quickly became one of the biggest migrant sending countries in Europe (Migration Data Portal, 2015; Fihel \& Okólski, 2017). with skilled low-cost labour in high demand in the western parts of the EU's common labour market. This development was accompanied by a slight increase in wages for medium-skilled workers in Poland, being the group with the largest relative outmigration rates (Dustmann et al., 2015; Brandt \& Sicari, 2016; Škuflić \& Vučković, 2018). In 2004, Poland had a considerable surplus of labour in construction. For construction industries in Western Europe, which were experiencing a huge upswing, this provided excellent opportunities to recruit labour from Poland - to an extent that few had anticipated before EU enlargement. Today, Poland still represents one of the biggest sending countries of skilled labour; however, the total number of emigrants is decreasing (Organisation for Economic Co-Operation and Development [OECD], 2019).

In the next section, we present the VET system in Poland and the construction sector. We then outline our analytical framework, which combines insights from the literature on institutional change, and Hirschman (1970) to analyse the impact of the EU's enlargement 
as an exogenous shock to the Polish labour market, before presenting the study's data and methods. The analysis distinguishes between the responses of VET policy and the strategies of employers. In the last section, the paper discusses whether the consequences of large-scale skilled emigration hold the capacity to (re)shape the Polish vocational educational research agenda by changing the attitudes and behaviours of policymakers and employers.

\section{The Polish VET System - In Flux}

The comparative literature offers different typologies of national VET systems organised in sets of key dimensions (see Rageth and Renold (2019) for a review). Following the typology developed by Pilz (2016), the Polish VET system can be characterised as a state-regulated, highly stratified, highly standardised system, with low levels of experience of labour market practice. There is a strong stratification between VET and general education pathways (although after completing technical school, learners might acquire a maturity diploma which provides access to higher education). VET suffers from disparity of esteem compared to academic education, despite promotional campaigns and governmental activities to change the negative image of VET. The share of the youth cohort opting for upper secondary VET decreased sharply from $80 \%$ in the 1990 s and has remained stable at $57 \%$ over the last decade. ${ }^{1}$

The Polish VET system is school based with limited involvement of employers at the stage of curriculum design, curriculum application and curriculum updating. It is the ministry of education and its agencies which are solely responsible for organising the curriculum design process, for the content of the exam and the organisation of teacher training. However, schools can develop learning programmes aligned with the national core curriculum. VET external examinations are also designed and conducted centrally by the Central Examination Board and supervised by eight regional examination boards. Employers - even if they are involved in these processes - play rather an advisory role. The share of enterprises employing IVET participants is also one of the lowest in Europe, at 7.5\% compared to an EU-28 average of $30.5 \%$. Weak employer involvement is considered one of the weakest aspects of the Polish VET system (Eurostat, 2015). Thus, recent VET reforms focus on providing better linkages between the VET system and the employment system.

The employment rate of initial VET graduates in 2016, at $74.3 \%$, was slightly lower than the EU average of 75\%. Recent VET graduates display substantially lower skills levels in literacy, numeracy and problem solving, which is especially evident among graduates of basic vocational school (Lis \& Miazga, 2016; OECD, 2019).

1 In the 2016/2017 school year there were 672,101 learners in upper secondary vocational education, representing $57 \%$ of all learners in upper secondary education. 


\section{The Construction Sector}

Construction is one of the largest sectors of the Polish economy, generating between 6 and $8 \%$ of GDP and providing employment for around $6 \%$ of employees. Construction services are provided by over 400,000 firms, of which $96 \%$ are smaller companies employing up to nine employees. This fragmentation, sensitivity to economic fluctuations, lowering profitability and a persistent skills gap - the unmet demand for qualified employees with high skills - are the most serious challenges faced by the sector (Sectoral Competences Council in the Construction Sector [SCCC], 2018; Rozkrut et al., 2020). The skills deficit is estimated to be around 100-150,000 qualified workers (Polish Agency for Enterprise Development [PARP], 2019). According to the Sectoral Competences Council in the construction sector (SCCC), the occupations in high demand are the technical levels: bricklayers, plasterers, carpenters, concrete workers, and steel fixers (SCCC, 2018).

At the same time, Poland receives a massive number of migrants from elsewhere in eastern Europe and is currently the top temporary labour migration destination (OECD, 2019). Thus, the question of labour market responses to mass skilled emigration needs to take the influx of low-cost labour into account. However, the unmet demand gap is not compensated for despite the mass immigration of workers from eastern countries, especially Ukraine (90\%), Belarus (4\%), Moldova and others. According to the Ministry of Labour, 900,000 official work permits were issued in the first half of 2019, 175,000 of these in the construction sector. It is estimated that this is only around half of the migrant workers employed in the sector, given the large grey economy and barriers in finding legal employment (Główny Urząd Statystyczny [GUS], 2019, Fundowicz et al., 2019; Growiec et al., 2019; Chmielewska et al., 2019).

The Polish VET system is comprised of more than 50 qualifications ${ }^{2}$ related to the construction sector, grouped in 20 occupations. According to the CVTS Eurostat survey, the share of employers in the construction sector involved in initial and continuing VET is among the lowest in Europe (Eurostat, 2015). In 2015, only 8.6\% of employers in the Polish construction sector were involved in initial VET provision compared to $39.9 \%$ in the EU-28, while $39 \%$ of employers were involved in continuing VET compared to $71.5 \%$ in the EU-28 (Eurostat, 2015).

2 In the Polish VET system, a qualification is understood as a set of learning outcomes following established standards, whose achievement was formally certified by a competent body. To acquire VET qualification a person needs to pass external exam organised central and regional examination boards. VET qualifications are referenced to the national and qualifications frameworks and the European Qualifications Framework. 


\section{Analytical Framework}

This paper combines theoretical insights derived from theories of institutional change with Hirschman's (1970) notions of exit, voice and loyalty. First, theories of institutional change have been some of the most innovative in the social sciences in the last decade, and we consider them particularly well suited to analyse the constellation of institutions that make up national VET systems. However, migration is just one element in the broader social processes of external and internal challenges forcing changes of VET systems around Europe (e.g. Cedefop, 2018). Thus, the effects of migration on national systems for vocational education emerge in interaction with cultural and institutional patterns. For the purpose of this paper, we define an institution as principally a set of rules or norms regulating the behaviour of individuals, as well as organizations and other corporate actors based on formal elements such as legislation, bureaucratic regulations and/or large-scale agreements (Engelstad \& Hagelund, 2015). It is a framework for action with a relatively high degree of stability, albeit subject to constant power struggles and negotiations (Thelen, 1999). However, a policy change might be elicited by exogenous shocks, like new technologies, war or economic crisis (Sabatier, 1988, p. 134). Such shocks open a "policy window of opportunity" for the creation of new rules and a new course of action (Kingdon, 2003). Exogenous shock might additionally prompt decision makers to examine the fundamentals of policy and encourage them to introduce more radical changes to policy within the process of policy learning (Heclo, 1974).

The second analytical strand we draw on in this paper is derived from Hirschman (1970), and addresses sources and processes of potential institutional change. His framework was originally developed to conceptualise ways of reacting to dissatisfaction with organisations and deterioration in business firms, which might result from shifts in supply and demand conditions in the organisation's competitive environment. Hirschman proposes three main types of responses for members of the organisation: Exit is for the member to quit the organization or for the customer to switch to the competing product (considered the most effective option). The second, voice, is for members or customers to exert influence for change "from within", either through individual action or collective action, appealing to higher authority. The last type of response is loyalty, which Hirschman perceives as a special emotional attachment to an organization. The presence of loyalty makes exit less likely and gives more scope to voice. Thus, the likelihood of voice increases with degree of loyalty. In this paper, we apply these three concepts to grasp employers' reactions when faced with skills shortages caused by mass skilled emigration. 


\section{$5 \quad$ Data and Methods}

This study is part of an international research project on how intra-European labour migration affects skill formation and utilisation in Norway and Denmark and in sending countries ("Moving trades. Skill formation and the role of national vocational training in transnational European labour markets", funded by the Research Council of Norway). A comprehensive qualitative study was undertaken to investigate how mass skilled emigration and consequential labour market changes affect VET policy and employers' attitudes towards their involvement in VET. The data collection was two-fold. First, qualitative interviews were chosen to identify in-depth subjective accounts and opinions of relevant actors. Second, analysis of VET policy documents was undertaken including strategic documents prepared by the government, legislative acts adopted and reports from the consultation process around these acts. The interviews were carried out in Warsaw, Poland during June 2018 - July 2019, covering a broad range of key stakeholders. Three groups were distinguished:

1. Decision makers responsible for VET policies and representatives of central VET agencies

2. Representatives of the labour market, i.e. representatives of employers' associations, chamber of Craft and trade unions

3. Representatives of the education sector, i.e. principals of vocational schools, VET teachers responsible for practical training and representatives of regional examination boards.

Decision makers from the Ministry of Education and the employees of the central VET agencies (Central Examination Board, Centre for Educational Development, Erasmus+ National Agency) were interviewed ( 9 interviewees) to gain knowledge about potential changes in VET policies, and the attitudes of employers regarding their willingness to contribute to the VET system by providing practical training or taking in apprentices. When covering representatives of the labour market (10 interviewees), we aimed to interview employers across various types of companies, i.e. large international construction companies, and medium and small-sized companies were included in the sample, as well as the Chamber of Craft. The main questions posed to employers were whether they were experiencing problems in recruiting personnel with the right skills, how they approach this challenge, whether the situation had changed over the past five years, whether emigration or immigration has affected their attitude towards involvement in VET and if so how. Interviewees from the education sector included principals of vocational schools, teachers responsible for practical training and representatives of regional examination boards ( 25 interviewees). The sample included schools of different sizes and from different regions (the west of the country is more developed than 
the east). This group of interviewees were asked about changes in employers' attitudes regarding involvement with VET, and perceptions of VET policy interventions around skilled emigration.

Altogether 44 interviews were conducted. Interviewees were identified through purposive sampling. This means including only people who meet a specific set of criteria, based on knowledge of the substantive field of study, recommendations from other researchers and the regional examination boards experts. Most of the interviews were conducted by telephone, but the interviews with policy makers in Warsaw were face-to-face. From the perspective of the purpose of this qualitative study and taking into consideration that social cues of the respondent were not important information sources, we treated telephone interviews as equivalent method of face-to-face interviews (cf. Opdenakker, 2006; Cachia \& Millward, 2011; Novick, 2008). Conducting telephone interviews allowed for much broader geographical coverage.

Prior to the interview, each interviewee was contacted via e-mail or telephone and was informed about the purpose of the study. Participation was based on informed consent. All interviews were conducted by the authors of the article. To limit interviewees' unease of discussing national policies, interviews were not recorded. Rather, in addition to notes during the interview, detailed field notes were written down immediately after the interview. Notes were then anonymised. All interviews lasted 45-60 minutes and followed a semi-structured interview guide. This entails having a predefined set of topics that we wanted to cover, but the order of topics and the relative time devoted to each topic was determined by the dynamics of the interview. The interviews gave room for interviewees to bring up additional aspects of the topic that were important to them.

The data was analysed according to thematic analysis, implying identifying patterns or themes within the data (cf. Alholjailan, 2012). The initial stage of analysis involved text-close coding and clustering data in terms of key topics, building inductively from particular to general themes. In the subsequent sections, VET policy and employers' responses are analysed.

\section{VET Policy Response}

During 2016-2019, radical reforms were implemented across several areas of policy including general education. After years of inattention, the VET system in Poland became the object of intensified policy actions at an unprecedented scale and pace. Creating an attractive educational offer for young people and adults has been a national priority since early 2010 . The exogenous shock that mass skilled emigration represented to the Polish labour market stimulated policy learning. Decision makers in Poland searched for solutions in VET to better adjust it to the current labour market and societal needs by inviting employers and VET school principals into the debate about future changes. A council of 42 vocational school 
principals was formed and series of seminars with employer representatives and debates were organised. These consultative meetings significantly contributed to the shape of the solutions adopted. Measures aimed at increasing employers' involvement in VET were also sought abroad, mostly in Germany, known for its dual VET system.

In 2012, a major curricular reform introduced units of learning outcomes. Since 2012 all VET qualifications can be attained via the validation of non-formal and informal procedures and more flexible learning pathways, especially for adults wanting to broaden their skills or acquire new ones. The scope and pace of reforming activities has intensified since $2016^{3}$ and materialised in changes to the major items of legislation in 2018-2019. The main aim of the 2018 reform was to bring the world of work closer to the world of education and to increase employers' involvement in education and training, especially within formal VET.

The interviews with policymakers and document analysis show that national decision makers actively responded to labour market tensions and deficits in qualified workers. The interviewees at policy level stated that this intense policy activity in the field of VET in recent years results from skills shortages caused by massive emigration and economic growth. Employers made use of "voice" (cf. Hirschman, 1970), demanding adequate skills policies and a skilled labour force, which was heard at the central decision-making level. This resulted in the formulation of national strategies strengthening the position of VET and adoption of new legislative solutions. EU-level policies in the field of VET and funds made available from EFS provided an additional impetus to reform efforts at the national and regional levels (Dębowski \& Stechly, 2015). Following Howlett et al's (2009) classification of policy response, we classify VET policy response in Poland as redesign. Polish VET decision makers made conscious efforts to restructure VET policy and respond adequately to current challenges. The main measures introduced 2018-2019 are described below.

1. Vocational schools providing education in a given occupation must now organise formal collaboration with relevant employers, e.g. participation in work-based learning, equipping school workshops, patronage classes or organising vocational exams. Previously, such collaboration was optional.

2. To establish training in new occupations, vocational schools are obliged to acquire permission from the voivodeship (regional) labour market council, consisting of local employers, representatives of trade unions, chamber of Craft and local authorities. Previously, opinions were collected mostly from the poviat (local) labour market councils and this was not binding.

3 In 2016, changes were introduced to the school system within formal general (primary and secondary) education and VET. As a result of these changes, 4-year secondary technical schools were transformed into 5-year technical secondary schools (technikum) for students aged 15-20 years. Basic vocational school (zasadnicza szkoła zawodowa) was transformed into the 3 -year stage I sectoral vocational school (szkoła branżowa I stopnia) for students aged 15-18 years. Learners attending a 3 -year stage I sectoral vocational school can then enter the labour market or attend a newly designed 2-year stage II sectoral vocational school (szkoła branżowa II stopnia). 
3. A new form of internship has been introduced (staż uczniowski) which complements previously existing arrangements to enhance employer participation in work-based learning. A new element in staż uczniowski is that it may extend the scope of the school curriculum. The costs of renumeration are treated as tax deductible costs for employers. Employers may transfer funds directly to the schools - for example if they wish to provide funds to buy equipment. Previously, all funds had to be transferred to local authorities.

4. Public VET funding is linked to the labour demand for specific occupations and to the cost of training. Up to now the financing algorithm provided similar per capita funding for different occupations. Schools providing education in occupations in higher demand will receive significantly more public funds. This change aims to incentivise VET school principals and local authorities to provide training in the occupations which are most in demand.

5. VET teachers are obliged to participate in professionally oriented training in enterprises, for at least 40 hours across a 3-year period. Previously, there was no such obligation. This aims to contribute to upgrading teachers' skills and competences, providing them with access to new technologies and enterprises in a given labour market sector.

6. From 2020, the VET exam will be mandatory for learners in all VET schools, which means that if a person does not participate in the VET exam, he/she cannot be promoted to the next class level and cannot obtain the certificate of school completion. The vocational examination system was recently cofounded with the Ministry of Labour Fund. The Ministry of Labour will cover almost $40 \%$ of the total cost of VET examinations in Poland.

To institutionalise the dialogue between VET stakeholders, including representatives of employers and employees, sectoral competence councils were formed with the support of ESF funds. Each council (SCC) represents main stakeholders of a sector and provides recommendations about skills needs, the content of core curricula and exam content. SCCs have been formed in 7 sectors. The Programme Council on Competences was set up to coordinate the work of the SCC. To increase employer involvement in designing exams, the Central Examination Agency, responsible for VET exams, has been setting up what are called national teams of experts for every occupation. In every team, the presence of an employer's representative is mandatory.

Parallel and in synergy with VET reform, Polish authorities have made significant effort to develop an Integrated Qualifications System (IQS) based on the national qualifications framework. Since 2017, all VET diplomas and certificates are referenced to the NQF and EQF. The essence of the IQS Act is the introduction of a set of consistent systemic solutions for qualifications awarded outside the formal general, vocational and higher education sys- 
tems, and the greater integration of all areas within which qualifications are awarded (formal general, vocational and higher education, regulated qualifications and market qualifications). Since 2017, more than 100 qualifications have been submitted to the IQS with the active involvement of employers. The IQS council consists of 29 members representing employers, employees, the education community, the scientific and professional communities, the training market, local government and the Central Examination Board (CKE). The IQS represents an important forum for employers to voice their expectations around the development of IQS and VET policy.

\section{$7 \quad$ Employers' Responses}

From the viewpoint of decision makers, VET school principals and teachers who participated in the study, increased activity by employers was observed both at the central and school levels. Employers significantly intensified their activity of expressing requests for reforms and government actions to provide a skilled labour force. Representatives of employers actively participate in the public debate regarding skill policies and in policy dialogue fora organised by national and regional authorities. They request meetings with decision makers and present their demands in bilateral meetings with the cabinet. Employers use EU funding and their own funds to finance initiatives aiming at improving the quality of competences of VET graduates, either by participation in developing learning curricula or partial qualifications or by participation in pedagogical experiments.

Interviewees report that employers are more willing now, compared to 5 years ago, to take on learners for practical training and to contribute to improving school equipment. Many VET school principals indicated that more than 5 years ago it was very difficult to invite employers to schools even for information seminars organised by schools devoted to discussing possible forms of cooperation with local employers. This has changed dramatically. Employers are now considerably more interested in VET, especially in taking on VET learners for practical learning.

Responses of Small Versus Large Companies

VET teachers distinguished between the approaches of small and medium-large construction companies, consistent with previous research (e.g., Strzebonska, 2017). According to VET teachers, the motivation of smaller companies to take VET learners for practical training is less about equipping them with the right skills and more about using them on the construction site as low-cost labour, seeking short-term benefits. As a result, these learners tend to be trained in a narrower set of skills. However, some schools also provided examples of very good cooperation with small construction companies which have been cooperating with schools for many years even before labour market problems occurred: 
We operate in a small town in which there is a good employer involvement, despite all of them being small companies - up to 10 persons. Companies engage only in taking learners for practical training, they do not take entire classes and there are no patron classes. They do not engage in curriculum development or participate in conducting VET exams but there is no problem for them in taking 2-3 learners to the construction site for practical training. (Principal of VET school)

If there were no medium-to-large companies in the immediate surroundings, this might pose challenges to schools in establishing labour market cooperation. Small companies do not have the resources to invest time in more systemic cooperation with schools in areas of collaboration (like patron classes or development of training programmes) beyond taking learners for practical training. Medium and larger sized companies typically have a dedicated human resources unit with more capacities and understanding of longer-term investment in the education and training of learners. They can also organise training to introduce different stages in the construction building process - therefore developing more broad skills among VET learners, whereas small companies usually specialise in a very specific task in a construction building process. A barrier for the involvement of smaller companies in the VET system is that many of them operate partially or fully in the grey economy, so they are not willing to take learners and to have official cooperation with schools, fearing that their practices might be reported to labour office or tax agencies.

Representatives of medium-sized and large companies said that they had to change their approach towards VET significantly. An owner of a 100-person construction company stated:

Before 2010, when unemployment was high, we could recruit skilled labour from the market quite easily. However, since a couple of years ago, the lack of workers has forced us to set up cooperation with a VET school. Two years ago, we launched a patron class of 10-15 learners, hoping that at least 1-2 learners will remain in our company. If more than 3 persons were employed, we would consider it a big success. It is a dramatic shift in our approach but is there any other way? (Employer of large construction company, Silesia region)

This employer felt there was no other option than to collaborate with the local VET school to access the skilled labour which the company relied on, acknowledging that a high proportion of the learners would leave the country post-training. The interviewees who represented labour market actors stated that the emigration of Polish skilled workers represented a huge challenge for them. 


\section{Impact of Migration}

While some employers chose to invest in the vocational education and training of learners to meet demand in their own company for skilled workers, for other employers, mass emigration constituted a significant barrier to investing in VET:

What is the point of investing my time and resources in young learners if it is more than certain that he will leave the country? A construction site is a very dynamic environment. One may participate in investment in region A and after some time in region B 200 kilometres away. What difference does it make if you are away from home in Poland or in another country? So very often employees choose to work for companies abroad. (Employer in a small construction company)

Regarding the immigration of (low-cost) workers to Poland, employers reported that they filled the skills gap only to a limited extent. Without workers from countries such as Ukraine and Belarus it would be more difficult to operate, yet the influx of immigrant (temporary) workers is seen as insufficient both in terms of numbers and skills. As a result of immigration, representatives of employers' organisations are more interested than before in instruments recognising skills. The decision makers interviewed said that employers now more frequently demand better and more flexible competence recognising procedures within the formal VET system and more flexible pathways to acquire qualifications. This study confirms that due to tensions between skills demand and supply, not only emigration but also immigration have tended to prompt more VET activity among employers and employers' organisations in Poland.

\section{VET Teachers and School Environment}

Some representatives of companies indicated that a barrier to cooperation was the attitude of VET school principals, and that their lack of flexibility impedes the involvement of employers in VET at the local level. This opinion was confirmed by VET school principals. One principal (principal of VET school) stated: "If you invest $0 \%$ of your time in setting up relations with employers, then you will receive $0 \%$ in investment."

During interviews it was also indicated that VET teachers are overloaded with work and do not have enough time to spend on setting up relations with employers. This might result from the fact that in many occupations there are not enough VET teachers and they often work overtime (which sometimes reaches the $150 \%$ monthly norm defined by law) (Lis \& Miazga, 2016). Employers also signalled that the character of the mandatory practical training was too limited (one month) for them to see the results of training efforts. This discouraged employers from investing heavily in training this group of learners. However, due to legislative changes in 2019 there will be more options for cooperation and for hiring learners 
by employers which should alleviate this problem, where periods of internship might be prolonged, and the learner will be able to receive remuneration.

\section{Social Dialogue}

One of the most significant factors affecting involvement of employers in VET relates to the school-driven VET system in Poland, and the weak traditions of social dialogue in the area of skills (Bukowski \& Dębowski, 2010). There is a general weakness of employers' and employees' associations and industrial relations models in Poland (Gardawski, 2009; Gardawski et al., 2012; Czarzasty \& Mrozowicki, 2018). Only small numbers of employers are represented by regional, branch or central organisations, and central organisations have very limited influence on their members - so even if central organisations reach any agreements with unions and decision makers at the central level, this is not sufficient, as members of these organisation may not implement the measures. Moreover, employers' organisations are not in a position to take responsibility for designing core curricula or exam content on their own. The interviewees from the examination system confirmed that employer involvement in designing core curricula and content of examinations is lacking. The involvement of employers in designing VET exams is time consuming and requires knowledge of the methodology for exam formulation which is too much burden for individual companies. To some extent alleviation of this problem might be setting up sectoral skills councils (see chapter 6)

\section{Discussion}

VET systems remain national, yet labour markets are becoming increasingly international. Faced with mass skilled emigration in the wake of EU enlargement, most pronounced in the construction sector, Polish VET stakeholders were faced with different choices. Drawing on Hirschman's (1970) concepts, one might imagine that stakeholders would scale down VET activity and withdraw from the system to find other training and recruitment alternatives, i.e. exit to avoid losing to emigration the skilled labour which has been the subject of considerable educational investment. Yet on the contrary this study finds that the overall response has been to increase the interest in VET. Institutional change may occur because political actors act to change the institutional framework by defining the purpose of a policy reform and the problems it is expected to solve, and by offering alternative policy instruments and appropriate methods.

Restoring the importance of VET and creating an attractive educational offer for young people and adults have become a national priority since 2010. Exceptionally high policy activity is partly explained as a response to skills deficits, and partly fuelled by EU-level policies and EU funds. Prior to EU enlargement in 2004, the common opinion among decision makers was that VET was not a reasonable or attractive path, and that Poland should rather 
place the emphasis on general and higher (academic) education, and that professional colleges could cater to those wanting to acquire professional skills as adults.

The puzzle of why companies train has typically been investigated through economic perspectives. Low economic investments made by employers, given the school-based VET system of Poland - as opposed to dual apprenticeship systems - seem to impose high costs on companies during the periods of practical training (Mohrenweiser \& Zwick, 2019). These findings reveal that skills shortages stemming from mass skilled emigration caused significant challenges, especially to medium sized and large construction companies, which depend on access to this type of labour. The findings are in line with the theoretical assumptions of Hirschman (1970); the less the availability of exit, the more likely it is that voice will be used. Given that actors are restricted by institutional regulation, they are often motivated to influence the structure and working of institutions, for example, by calling for legislative reform (Engelstad et al., 2017). Employers' strategies were to become more involved in VET at the central level in designing policies and voicing for reform of the education system. They are also more involved at the school level in taking on learners for practical training and equipping schools with machinery etc. Thus, employers do largely remain loyal and at the same they used voice for policy actions. However, these responses were not necessarily shared by smaller construction companies, due to lesser resources and perhaps some of them due to operating in the grey economy. An influx of low-cost temporary labour from eastern European countries might contribute to depressing wages and making VET a less attractive path for aspiring learners.

Institutional change is difficult - stability and inertia prevail; the last 25 years of efforts of changing VET in Poland are proof of that. The literature perceives institutional change as generally incremental rather than sudden, i.e. as an accumulation of a range of small changes rather than occasional large changes (North, 1990). Such path dependent mechanisms are also evident in the case of Polish VET, despite the quite sudden mass skilled emigration in the wake of the opening of the European labour markets. Despite a range of recent policy actions and legislative efforts, several major challenges in the Polish VET system remain unresolved. VET is perceived as a second best-option among learners and their parents. Thus, continuous effort is needed to promote VET and increase its attractiveness. This also goes for attracting VET teachers. Currently, there is an acute shortage of competent VET teachers. Regardless of intensified policy activity and great labour market demand, the number of VET learners has not increased. Furthermore, there are challenges to employers' participation in a highly school-based VET system. Employers would need to achieve a sense of ownership of the VET system in order to be willing to make the (currently highly uncertain) investments involved. Still, there is a large proportion of passive employers. Continued efforts to institutionalise and enhance the dialogue between the system of education and the labour market appear as the most pressing need. The study showed that one of the most significant obstacles for em- 
ployers investing in the training of VET learners is the fear of losing a young skilled employee due to emigration. Yet, dependent on skilled labour, employers of big construction companies saw no other option than to continue investing in training young learners.

To compete with low-cost unskilled labour in the construction sector, the VET system would need to be more competitive in the quality rather than the price of their products, to be able to justify increased wages. Poland will continue to face significant skilled emigration, potentially inhibiting employers from being involved in the education system. The costs of these outflows of skills and labour might be a reduction in the overall potential of economic development, serious skills and workforce deficits, and undermined innovation processes (Duszczyk et al., 2013). However, strong commitment and intensified state level policy action hold promises for a renewed and improved agenda for VET in Poland. Decision makers make great efforts to restructure VET policy and respond adequately to current challenges. This state-level response is in synergy with employers' responses. In this way, large scale skilled emigration might contribute to a positive shift in VET policy, although it is currently too soon to tell whether this will bring about permanent changes.

\section{References}

Alholjailan, M. I. (2012). Thematic analysis: A critical review of its process and evaluation. West East Journal of Social Sciences, 1(1), 39-47. https://pdfs.semanticscholar.org/688d/4a3fbeada5adfc67c8 b2b8f5a6d7355ab94c.pdf

Andersen, R., Bråten, M., Eldring, L., Friberg, J. H., \& Ødegård, A. M. (2009). Norske bedrifters bruk av østeuropeisk arbeidskraft [Norwegian enterprises' use of Eastern European labour]. Fafo-report 2009: 46. Fafo.

Beine, M., Docquier, F., \& Rapoport, H. (2001). Brain drain and economic growth: Theory and evidence. Journal of Development Economics, 64(1), 275-289. https://doi.org/10.1016/j.jdeveco.2004.03.008

Black, R., Engbersen, G., Okólski, M., \& Panțuru, C. (2010). A continent moving west?: EU enlargement and labour migration from central and eastern Europe. IMISCOE Research. Amsterdam University Press.

Bolli, T., Caves, K., Renold, U., \& Bürgi, J. (2018). Beyond employer engagement: Measuring education-employment linkage in vocational education and training programmes. Journal of Vocational Education and Training, 70(4), 523-563. https://doi.org/10.1080/13636820.2018.1451911

Brandt, N., \& Sicari, P. (2016). The skills of Polish emigrants: Evidence from PIAAC. OECD Economics Department Working Papers, No. 1332. OECD Publishing. https://doi.org/10.1787/5jlpq7tg3hxsen

Bukowski, M., \& Dębowski, H. (2010). Social dialogue in the changing labour market. In M. Bukowski (Ed.), Employment in Poland - 2009 (pp. 131-176). Institute for Structural Research/Ministry of Labour and Social Policy, Warsaw.

Cachia, M., \& Milward, L. (2011). The telephone medium and semi-structured interviews: A complementary fit. Qualitative Research in Organizations and Management. An International Journal, 6(3), 265-277. https://doi.org/10.1108/17465641111188420 
Campanella, E. (2015). Reversing the elite brain drain: A first step to address Europe's skills shortage. Journal of International Affairs, 68(2), 195-209. https://blogs.cuit.columbia.edu/jia/ files/2015/05/195-209_Campanella.pdf

Campo, F., Forte, G., \& Portes, J. (2018). The impact of migration on productivity and native-born workers' training. IZA Discussion Paper No. 11833. IZA.https://ssrn.com/abstract=3261692

Chłoń-Domińczak, A., Dębowski, H., Drogosz-Zabłocka, E., Dybaś, M., Holzer-Żelażewska, D., Maliszewska, A., \& Tomasik, M. (2011). Edukacja zawodowa w Polsce. [Vocational education in Poland]. In A. Wojciuk \& M.Fedorowicz (eds.), Raport o stanie edukacji. Kontynuacja przemian (pp. 169-239). Instytut Badań Edukacyjnych.

Chmielewska, I., Panuciak, A., \& Strzelecki, P. (2019). Informacja z badań ankietowych imigrantów w Bydgoszczy i we Wrocławiu w 2018 i 2019 roku [Information from surveys of immigrants in Bydgoszcz and Wrocław in 2018 and 2019]. Narodowy Bank Polski.

Czarzasty, J., \& Mrozowicki, A. (2018). Industrial relations in Poland: Historical background, institutional evolution and research trends. Employee Relations, 40(4), 674-691. https:/doi.org/10.1108/ ER-04-2017-0082

Dębowski, H., \& Stęchły, W. (2015). Implementing ECVET principles. Reforming Poland's vocational education and training through learning outcomes based curricula and assessment. In Warsaw Forum of Economic Sociology (Vol. 6, No. 12, pp. 57-88).

Dustmann, C., Frattini, T., \& Rosso, T. (2015). The effect of emigration from Poland on Polish wages. The Scandinavian Journal of Economics, 117(2), 522-546. http://dx.doi.org/10.1111/sjoe.12102

Duszczyk, M., Góra, M., \& Kaczmarczyk, P. (2013). Costs and benefits of labor mobility between the EU and the Eastern partnership countries: The case of Poland. IZA Discussion Paper No. 7664, October 2013. IZA.

Engelstad, F., \& Hagelund, A. (2015). Introduction: Institutional change in neo-corporatist society. In F. Engelstad \& A. Hagelund (Eds.), Cooperation and Conflict the Nordic Way. Work, Welfare, and Institutional Change in Scandinavia. DeGruyter. https://doi.org/10.1515/9783110436891

Engelstad, F., Larsen, H., Rogstad, J., \& Steen-Johnsen, K. (2017). Introduction: The public sphere in change. Institutional perspectives on neo-corporatist society. In F. Engelstad, H. Larsen, J. Rogstad $\&$ K. Steen-Johansen (Eds.), Institutional change in the public sphere. Views on the Nordic Model. De Gruyter Open. https://doi.org/10.1515/9783110546330

European Centre for the Development of Vocational Training. (2018). The changing nature and role of vocational education and training in Europe. Volume 3: the responsiveness of European VET systems to external change (1995-2015). Cedefop research paper; No 67. Publications Office. https://doi.org/10.2801/621137

Eurostat. (2015). CVTS survey [Data set: version of 26/02/2019]. https://ec.europa.eu/eurostat/web/ microdata/continuing-vocational-training-survey

Fihel, A., Okólski, M. (2017). Ageing in Poland in the conditions of intensive international migration. In P. Lewandowski, J. Rutkowski (eds.), Population Ageing, Labour Market and Public Finance in Poland, European Commission Representation in Poland (pp. 35-40). European Union. https://doi. org/10.2775/9

Fundowicz, J., Łapiński, K., Wyżnikiewicz, B., Wyżnikiewicz, D. (2019). Szara strefa 2019 [Grey economy 2019], Instytut Prognoz i Analiz Gospodarczych Fundacja Naukowa.

Gardawski, J. (2009). Polacy pracujący a kryzys fordyzmu [Working poles and the crisis of fordism]. Wydawnictwo Naukowe Scholar. 
Gardawski, J., Mrozowicki, A., \& Czarzasty, J. (2012). History and current developments of trade. Unionism in Poland. Warsaw Forum of Economic Sociology, 3(1), 9-50. Szkoła Główna Handlowa w Warszawie. https://ssl-kolegia.sgh.waw.pl/pl/KES/struktura/IFSISE/Documents/1.Juliusz_ Gardawski,Adam_Mrozowicki_and_Jan_Czarzasty,History_and_Current_Developments_of_ Trade_Unionism_in_Poland.pdf

Główny Urząd Statystyczny. (2019), Unregistered employment in Poland in 2017, Statistics in Poland, Warsaw. https://stat.gov.pl/obszary-tematyczne/rynek-pracy/pracujacy-bezrobotni-biernizawodowo-wg-bael/praca-nierejestrowana-w-polsce-w-2017-roku,22,5.html

Growiec, J., Wyszyński, R., \& Strzelecki, P. (2019). The contribution of immigration from Ukraine to economic growth in Poland, Narodowy Bank Polski, Warszawa.

Hardy, J., Eldring, L., \& Schulten, T. (2012). Trade unions responses to migrant workers from the "new Europe": A three sector comparison in the UK, Norway and Germany. European Journal of Industrial Relations, 18(4), 347-363. https://doi.org/10.1177/0959680112461464

Heclo, H. (1974). Modern social politics in Sweden and Britain: From relief to income maintenance. Yale University Press.

Hirschman, A. O. (1970). Exit, voice, and loyalty: Responses to decline in firms, organizations, and states. Harvard University Press.

Howlett, M., Ramesh, M., \& Perl, A. (2009). Studying public policy: Policy cycles and policy subsystems (3rd ed.). Oxford University Press.

Janicka, A., \& Kaczmarczyk, P. (2016). Mobilities in the crisis and post-crisis times: Migration strategies of Poles on the EU labour market. Journal of Ethnic and Migration Studies, 42(10), 1693-1710. https://doi.org/10.1080/1369183X.2016.1162350

Kingdon, J. (2003). Agendas, alternatives, and public policies (2nd ed.). Pearson.

Lis, M., \& Miazga, A. (2016). Ocena jakości polskiego systemu kształcenia zawodowego z perspektywy potrzeb rynku pracy [Labour market perspective on the quality of vocational education in Poland]. EDUKACJA Quarterly, 136(1), 5-22.

Migration Data Portal. (2015). Key migrations statistics. https://migrationdataportal.org/?i=stock_ abs_\&t=2019

Mohrenweiser, J., \& Zwick, T. (2019). Why do firms train apprentices? The net cost puzzle reconsidered. ZEW Discussion Paper No. 08-019. Centre for European Economic Research. ftp://ftp.zew.de/pub/ zew-docs/dp/dp08019.pdf

Nica, E. (2015). Labor market determinants of migration flows in Europe. Sustainability, 7(1), 634647. https://doi.org/10.3390/su7010634

North, D. (1990). Institutions, institutional change and economic performance. Cambridge University Press.

Novick, G. (2008). Is there a bias against telephone interviews in qualitative research? Research in Nursing \& Health, 31(4), 391-398. https://doi.org/10.1002/nur.20259

Organisation for Economic Co-operation and Development. (2019). International migration outlook 2019. OECD Publishing. https://doi.org/10.1787/c3e35eec-en

Opdenakker, R. (2006). Advantages and disadvantages of four interview techniques in qualitative research. Forum: Qualitative Social Research, 7(4), Article 11. https://dx.doi.org/10.17169/fqs-7.4.175

Panzaru, C., \& Reisz, R. D. (2017). Brain drain migration from Romanian academia. The end of a mirage. European Review of Applied Sociology, 10(14), 34-48. https://doi.org.10.1515/eras-2017-0003 
Pilz, M. (2016). Typologies in comparative vocational education: Existing models and a new approach. Vocations and Learning, 9(3), 295-314. https://doi.org/10.1007/s12186-016-9154-7

Polish Agency for Enterprise Development. (2019). Drenaż mózgów, czyli migracje potencjału intelektualnego. [Brain drain or migrations of intellectual potential].

Rageth, L., \& Renold, U. (2019). The linkage between the education and employment systems: Ideal types of vocational education and training programs. KOF Working Papers, No. 432, July 2017. KOF Swiss Economic Institute.

Rozkrut, M., Kowalczyk, A., Boguszewski, R. (2020). Raport z badania z sektora budowlanego 2019 [Report from the Survey Analysis of the Construction Sector]. Bank Gospodarstwa Krajowego (BGK)

Sabatier, P. A. (1988). An advocacy coalition framework of policy change and the role of policy-oriented learning therein. Policy sciences, 21(2-3), 129-168. https://doi.org/10.1093/oxfordhb/9780199646135.013.24

Sectoral Competences Council in the Construction Sector. (2018). Raport nr $1 \mathrm{z}$ monitorowania wybranych problemów sektora budowlanego pod kątem zapotrzebowania na kwalifikacje zawodowe i specjalności. [Report No. 1 on Monitoring Selected Problems of the Construction Sector in Terms of the Demand for Professional Qualifications and Competences]. Sectoral Council for Competences in Construction/Polish Agency for Enterprise Development.

Škuflić, L., \& Vučković, V. (2018). The effect of emigration on unemployment rates: The case of EU emigrant countries. Economic Research-Ekonomska Istraživanja, 31(1), 1826-1836. https://doi.org /10.1080/1331677X.2018.1516154

Strzebońska, A. (2017). Doświadczenia Polskiego Sektora MŚP w Zakresie Organizacji Programów Praktyk $i$ Staży [Experiences of the Polish SME Sector in the Organization of Internship and Apprenticeship Programs]. Polish Agency for Enterprise Development.

Thelen, K. (1999). Historical Institutionalism in Comparative Politics. Annual Review of Political Science, 2, 369-404. https://doi.org/10.1146/annurev.polisci.2.1.369

Toppin, I. (2018). Who is going to build the wall? A building trades crisis in the U.S.A. International Journal for Research in Vocational Education and Training, 5(1), 64-76. https://doi.org/10.13152/ IJRVET.5.1.4

\section{Biographical Notes}

Kaja Reegård ( $\mathrm{PhD}$ Sociology) is a senior researcher at the Nordic Institute for Studies in Innovation, Research and Education (NIFU) in Oslo, Norway. Her research interests include vocational education and training, apprenticeships, vocational students' engagement, dropout and school-to-work transitions.

Horacy Debowski is a researcher at SGH Warsaw School of Economics and vice director of the Central Examination Board in Poland. He is a member of the European Qualifications Framework Advisory Group to the European Commission. His research interests include vocational education and training policies including the design and development of qualifications frameworks. 